\title{
Sistem Pendukung Keputusan untuk Menentukan Penerima Bantuan Sosial Menerapkan Weighted Product Method (WPM)
}

\author{
Diana $^{\# 1}$, Iin Seprina ${ }^{\# 2}$ \\ ${ }^{\text {\#} F a k u l t a s ~ I l m u ~ K o m p u t e r, ~ U n i v e r s i t a s ~ B i n a ~ D a r m a ~}$ \\ Jalan A. Yani No 3 Plaju Palembang, 30264, Indonesia \\ ${ }^{1}$ diana@binadarma.ac.id \\ 2iin_seprina@binadarma.ac.id
}

\begin{abstract}
Abstrak - Efektifitas program bantuan sosial ditentukan oleh kesesuaian sasaran berdasarkan aturan atau kriteria yang telah disepakati. Permasalahan pada penyaluran bantuan sosial adalah distribusi bantuan kepada masyarakat miskin yang belum merata, dan sasaran program yang belum efektif. Untuk mengatasi permasalahan ini dibangun Sistem Pendukung Keputusan (SPK) menerapkan Weighted Product Method (WPM) untuk mengatasi kesalahan dan kecurangan yang dilakukan oleh pihak tertentu serta menghasilkan keputusan yang lebih objektif. Ada 5 kriteria yang digunakan yaitu penghasilan per bulan $\left(C_{1}\right)$, luas bangunan per orang $\left(C_{2}\right)$, jenis lantai rumah $\left(C_{3}\right)$, anak usia 7-15 tahun tidak sekolah $\left(\mathrm{C}_{4}\right)$ dan pendidikan terakhir kepala keluarga $\left(\mathrm{C}_{5}\right)$. Hasil pengujian berdasarkan uji stabilitas dimensi tungal menunjukkan bahwa WPM merupakan metode yang cukup stabil. Diperoleh 21,6\% posisi peringkat peserta $\mathrm{PKH}$ sangat stabil yang artinya posisi peserta PKH ini tidak berubah pada 6 uji variasi bobot kriteria, diperoleh $67,5 \%$ posisi posisi peringkat peserta PKH cukup stabil. Peserta PKH nomor 90 merupakan peserta yang konsisten selalu berada pada posisi pertama yang berarti peserta ini "paling miskin" diantara peserta yang lainnya, peserta ini memiliki nilai kriteria $C_{1}$ dan $C_{2}$ yang rendah dan memiliki nilai kriteria $C_{3}, C_{4}$ dan $\mathrm{C}_{5}$ yang tinggi. Peserta PKH nomor 219 juga konsisten berada diposisi terakhir yang berarti peserta ini "paling kaya" diantara peserta yang lain, peserta ini memiliki nilai kriteria $\mathrm{C}_{1}$ dan $\mathrm{C}_{2}$ yang tinggi dan memiliki nilai kriteria $\mathrm{C}_{3}$, $\mathrm{C}_{4}$ dan $\mathrm{C}_{5}$ yang rendah. Pada WPM, solusi yang dihasilkan adalah solusi ideal yang meminimumkan kriteria biaya dan memaksimumkan kriteria keuntungan.
\end{abstract}

Kata kunci - Sistem Pendukung Keputusan, Multi Criteria Decision Making, Weighted Product Method, Bantuan Sosial, Program Keluarga Harapan

\section{Pendahuluan}

Bantuan sosial adalah bantuan berupa uang, barang, atau jasa kepada seseorang, keluarga, kelompok atau masyarakat miskin, tidak mampu, dan atau rentan terhadap risiko sosial. Risiko sosial adalah kejadian atau peristiwa yang dapat menimbulkan potensi terjadinya kerentanan sosial yang jika tidak diberikan bantuan sosial akan semakin terpuruk dan tidak dapat hidup dalam kondisi wajar. Bantuan sosial ini diberikan dalam rangka program penanggulangan kemiskinan yang meliputi perlindungan sosial, jaminan sosial, pemberdayaan sosial, rehabilitas sosial dan pelayanan dasar. Dalam penelitiannya, [1] menuliskan bahwa bantuan sosial yang signifikan mempengaruhi pertumbuhan ekonomi terutama daerah tertinggal adalah bantuan ekonomi dan dunia usaha, bantuan kelembagaan sosial dan bantuan infrastruktur. Program bantuan sosial ini terbukti berdampak terhadap pertumbuhan ekonomi dan penanggulangan kemiskinan.

Pada saat ini, kemiskinan di Indonesia masih tergolong tinggi, masih merupakan masalah utama dan kompleks yang membutuhkan penyelesaian yang nyata. Kemiskinan dapat diminimalisasi dengan berbagai upaya dan tekad yang kuat dari pemerintah. Mengeluarkan kebijakan yang memihak kepada masyarakat miskin sehingga dapat memberantas kemiskinan dan meningkatkan kesejahteraan masyarakat miskin. Pemerintah melalui Kementerian Sosial telah mengeluarkan berbagai jenis bantuan sosial untuk menekan tingkat kemiskinxan yang ada di masyarakat, salah satunya adalah Program Keluarga Harapan (PKH). Program Keluarga Harapan merupakan program pemberian bantuan sosial bersyarat dalam bentuk Conditional Cash Transfers (CCT) kepada Keluarga Penerima Manfaat (KPM) yang memenuhi kriteria yang telah ditentukan. Upaya untuk mempercepat penanggulangan kemiskinan dengan program kegiatan CCT terbukti cukup berhasil dalam menanggulangi kemiskinan yang dihadapi beberapa negara, terutama masalah kemiskinan kronis. Sasarannya adalah ibu hamil, ibu menyusui, memiliki anak balita dan anak usia sekolah setingkat SD-SMP guna meningkatkan kualitas Sumber Daya Manusia dibidang kesehatan dan pendidikan. Tujuan program ini adalah untuk mengurangi beban ekonomi bagi Keluarga Penerima Manfaat guna 
memutuskan mata rantai kemiskinan bagi generasi berikutnya.

Masalah dalam pemberian dana bantuan sosial adalah adanya keterbatasan dana yang akan disalurkan sementara itu terjadi kemiripan data keadaan ekonomi penerima bantuan sosial sehingga perlu untuk merangking data penerima bantuan sosial berdasarkan kriteria yang telah ditentukan. Selain itu, masalah lain adalah adanya subjektifitas pengambilan keputusan yang menyebabkan bantuan belum tepat sasaran, keadaan ini menyebabkan masyarakat yang lebih pantas menerima dana bantuan sosial tidak mendapatkan haknya sebagaimana seharusnya atau dapat dikatakan bahwa target penerima bantuan sosial yang tidak tepat sasaran. Masyarakat yang sebenarnya tidak layak untuk mendapat bantuan sosial justru mendapat bantuan, demikian sebaliknya masyarakat yang layak mendapatkan bantuan sosial justru tidak mendapatkan bantuan. Menurut [2] permasalahan pada distribusi bantuan adalah tidak meratanya distribusi bantuan kepada masyarakat miskin dan terjadi masih terjadi ketidaktepatan dalam menentukan sasaran program.

Ketepatan sasaran akan menentukan efektifitas suatu program, dilihat dari kesesuaian dengan sasaran yang telah ditetapkan berdasarkan aturan atau kriteria yang telah disepakati. [2] Ada tiga faktor penghambat efektivitas PKH di kelurahan Rowosari, salah satunya ketepatan layanan yang belum berjalan baik, pada bidang pendidikan dan kesejahteraan sosial masih terdapat sasaran yang tidak tercakup menjadi keluarga penerima manfaat. Dalam tulisannya, [3] menuliskan bahwa efektivitas PKH berpengaruh secara signifikan dalam menanggulangi kemiskinan di Kota Utara, namun program ini masih belum berjalan sebagaimana mestinya, akibat dari program yang masih belum tepat sasaran kepada masyarakat yang benar-benar membutuhkan.

Ketepatan dalam menentukan Keluarga Penerima Manfaat yang tercatat dalam Basis Data Terpadu sangatlah penting agar bantuan diterima oleh keluarga yang tepat sasaran. Oleh karena itu, perlu sebuah penelitian untuk menentukan penerima bantuan sosial PKH sehingga distribusi bantuan keluarga sasaran program. [4] menuliskan bahwa dalam menentukan keluarga miskin diperlukan sebuah sistem informasi yang baik untuk mencegah kesalahan-kesalahan dan kecurangan-kecurangan yang dilakukan oleh pihak-pihak tertentu, dalam hal ini digunakan sistem pendukung keputusan.

Pada tulisan ini, Weighted Product Method (WPM) akan diimplementasikan pada sistem pendukung keputusan yang dibangun. Kelebihan metode ini antara lain, [5] WPM dapat digunakan dalam MCDM tunggal maupun multidimensi, dan [6] metode WP memberikan hasil yang lebih menyeluruh daripada metode SAW serta menurut [7] WPM lebih cepat daripada metode SAW.

\section{TinjauAn Pustaka}

\section{A. Multi Criteria Decision Making (MCDM)}

[8] Perkembangan publikasi MCDM sampai tahun 2015 mencapai 500 publikasi. Bahasan yang dibahas meliputi tentang ekonomi, ekonometrika dan keuangan (4\%), ilmu lingkungan (10,3\%), ilmu kemasyarakatan $(11,4 \%)$, obat $(12,3 \%)$, bisnis, manajemen dan akuntansi $(13,4 \%)$, teknik (34,3\%), ilmu komputer (33\%), matematika $(18,9 \%)$ dan ilmu keputusan $(17 \%)$.

Dalam MCDM, nilai masing-masing alternatif ke-i untuk setiap kriteria ke-j direpresentasikan dalam bentuk matriks keputusan, $\mathrm{X}_{\mathrm{ij}}$.

$$
X_{\text {if }}=\left[\begin{array}{cccc}
x_{11} & x_{12} & \ldots & x_{1 m} \\
x_{21} & x_{22} & \ldots & x_{2 m} \\
\vdots & \vdots & \cdots & \vdots \\
x_{\mathrm{m} 1} & x_{\mathrm{m} 2} & \ldots & x_{\mathrm{mm}}
\end{array} \mid\right.
$$

Dimana terdapat himpunan A yang berisikan sejumlah alternatif atau atribut, $A=\left\{A_{i} \mid \mathrm{i}=1,2, \ldots, n\right\}$ dan terdapat himpunan $\mathrm{B}$ yang berisikan sejumlah kriteria, $\mathrm{B}=$ $\left\{B_{j}, j=1,2, \ldots, m\right\}$ serta Nilai $X_{i j}$ adalah nilai untuk alternatif ke i untuk kriteria ke j. Tujuannya adalah menentukan alternatif-alternatif terbaik dari sejumlah $n$ buah alternatif yang ada berdasarkan pada $\mathrm{n}$ buah kriteria / ketetapan yang telah disepakati dengan melakukan perankingan nilai alternatif.

Proses pengambilan keputusan dalam MCDM akan melibatkan beberapa kriteria. [9] Pendekatan MCDM dalam memilih lokasi energi surya, kriteria utama dalam pemilihan lokasi adalah ekonomi, lingkungan, risiko, geografi, visi, ekology, masyarakat dan iklim. Kriteria utama untuk memilih teknologi surya adalah aspek teknik, aspek ekonomi, kelayakan, efisiensi, penggunaan lahan, fleksibilitas, emisi CO, keandalan dan akurasi. [10] pendekatan MCDM dalam memilih karyawan baru terdapat beberapa kriteria, antara lain pendidikan terakhir, kesesuaian jurusan, IPK, usia, pengalaman kerja dan kesesuaian pengalaman. Tujuannya adalah menentukan alternatif terbaik berdasarkan kriteria yang ada.

\section{B. Sistem Pendukung Keputusan}

Menurut [11], Sistem pendukung keputusan memungkinkan pengambil keputusan untuk menghasilkan keputusan dalam waktu yang lebih cepat (efisiensi waktu) karena dukungan sistem dapat memproses data dalam jumlah yang besar dengan cepat dan dapat menghasilkan keputusan yang sesuai dengan tujuan (efisien). Sistem pendukung keputusan ini tidak mengantikan kedudukan pengambil keputusan, namun hanya sebagai aplikasi pendukung dalam proses pengambilan keputusan. [12] juga menuliskan bahwa sistem pendukung keputusan hanya membantu proses menyeleksi warga yang berhak mendapatkan dana bantuan kartu jaminan kesehatan masyarakat, keputusan sepenuhnya diserahkan kepada Kelurahan Kaliwadas Kecamatan Sumber. [13], Decision Support System (DSS) sebagai penasehat bagi pembuat 
keputusan dalam kerangka model yang sesuai untuk meningkatkan pengambilan keputusan, dimana DSS tidak memutuskan dan penilaian manajer itu penting. Beberapa penelitian telah dilakukan antara lain, [14], menghasilkan sistem pendukung keputusan penentuan bantuan keluarga miskin dan diperoleh tingkat akurasi sistem mencapai diatas $80 \%$ dengan menerapakan AHP-PROMETHE II. Dalam penelitiannya [15], menghasilkan sistem pendukung keputusan kelayakan pemberian bantuan dana kredit untuk UKM pada Bank Negara Indonesia (BNI) menerapkan SAW dan dengan adanya SPK ini, proses penyeleksian dan penentuan calon penerima bantuan data dapat lebih terseleksi dan hasil keputusan dapat lebih objektif. [16] menganalisis dan mendesain SPK untuk meningkatkan kualitas pendidikan di sekolah menerapkan WPM dan metode borda.

\section{Weighted Product Method}

Weighted Product Method (WPM) merupakan salah satu metode yang digunakan pada MCDM. Metode ini banyak digunakan dalam berbagai aplikasi sistem pendukung keputusan. [17], WPM dapat membuktikan proses penyeleksian produk berbasis teknologi berupa notebook dengan hasil yang optimal. [10] mengimplementasikan WPM pada sistem penerimaan pegawai baru PT. Tiga Serangkai Pustaka Mandiri Surakarta, penelitian ini menghasilkan fakta bahwa hasil pengujian fungsionalitas membuktikan kinerja sistem yang dapat berjalan sesuai dengan kebutuhan fungsional dan hasil pengujian validitas membuktikan tingkat akurasi perhitungan aplikasi web sebesar $80 \%$, sehingga dapat dikatakan bahwa metode WP memiliki kinerja sistem yang baik sehingga layak untuk diterapkan. [18] menerapkan WPM untuk simulasi pemilihan PC tablet, WPM berfungsi sebagai sarana untuk memberikan rekomendasi produk kepada pengguna tentang produk yang paling cocok untuk mereka berdasarkan mekanisme peringkat.

Langkah-langkah pada Weighted Product Method adalah sebagai berikut :

1) Terdapat data alternatif berupa data penerima program keluarga harapan, $A=\left\{A_{i} \mid A_{i}\right.$ adalah calon penerima $\mathrm{PKH}\}$, dan terdapat data kriteria, $\mathrm{B}=\left\{\mathrm{B}_{\mathrm{j}} \mid \mathrm{B}_{\mathrm{j}}\right.$ adalah kriteria syarat penerima $\mathrm{PKH}\}$. Data masing-masing alternatif ke i untuk masing-masing kriteria ke $\mathrm{j}$ direpresentasikan dalam bentuk matriks $X_{\mathrm{ij}}$.

2) Menentukan bobot kriteria untuk masing-masing kritera, $\mathrm{W}=\left\{\mathrm{W}_{\mathrm{j}} \mid \mathrm{W}_{\mathrm{j}}\right.$ adalah bobot kriteria ke $\left.\mathrm{j}\right\}$, lalu melakukan normalisasi bobot kriteria.

3) Menentukan kriteria keuntungan dan kriteria biaya. Menurut [17], langkah ini sangat penting diperhatikan karena dengan kesalahan persepsi akan mengakibatkan keterbalikan fakta terhadap keputusan yang diperoleh. Dimana, kita menentukan kriteria yang dijadikan parameter penilaian, ditentukan kriteria yang memberikan sifat keuntungan (benefit) sebagai nilai positif dan kriteria yang memberikan sifat pengeluaran (cost) sebagai nilai negatif.

4) Menghitung nilai vektor $S$

Nilai vektor (S) diperoleh dengan cara memangkatkan nilai atribut dengan nilai normalisasi bobot kriteria, $\mathrm{W}_{\mathrm{j}}$. Ketentuan yang berlaku adalah untuk kriteria yang termasuk dalam kriteria biaya maka nilai pangkat bernilai negatif sedangkan untuk kriteria yang termasuk dalam kriteria keuntungan maka nilai pangkat bernilai positif. Nilai preferensi untuk setiap alternatif adalah :

$$
S_{i}=\Pi_{j=1}^{m} x_{i j} W_{j}^{*}
$$

5) Menghitung nilai Vektor V.

$$
V_{i}=\frac{n_{j=1}^{n} x_{i j}^{w j}}{n_{j=1}^{m}\left(x_{i j}^{n}\right)^{W j}}
$$

Nilai pada vektor $\mathrm{V}$ merupakan nilai akhir pada metode ini yang menunjukkan skor untuk masingmasing alternatif, semakin besar nilai vektor $\mathrm{V}$ untuk alternatif ke i maka semakin besar peluang alternatif itu terpilih sebagai alternatif yang diinginkan oleh pengambil keputusan.

\section{METODOLOGI PENELITIAN}

\section{A. Data Penelitian}

Dataset yang digunakan pada penelitian ini berupa dokumen penerima bantuan sosial PKH pada Kecamatan Ilir Barat I Dinas Sosial Kota Palembang sebanyak 292 orang. Data ini meliputi No. PKH, nama peserta, alamat, kelurahan, kecamatan, jumlah anak, pekerjaan, tempat tinggal yang meliputi luas bangunan per orang dan jenis lantai, anak usia 7-15 tahun yang tidak sekolah, pendidikan teakkhir kepala keluarga, keterangan dan pendamping. Selain itu pada penelitian ini disebarkan 35 kuisioner kepada pendamping $\mathrm{PKH}$ untuk menentukan menentukan bobot kriteria. Kuisioner menggunakan skala linkert dengan ketentuan Sangat Penting Sekali (SPS) dengan skor 5, Sangat Penting (SP) dengan skor 4, Cukup Penting (CP) dengan skor 3, Tidak Penting (TP) dengan skor 2 dan Sangat Tidak Penting (STP) dengan skor 1.

\section{B. Kriteria dan Bobot Kriteria}

Setiap kriteria dalam MCDM memiliki bobot yang menunjukkan tingkat kepentingan relatif setiap kriteria yang dapat ditentukan oleh seorang pengambil keputusan atau beberapa orang pengambil keputusan. Nilai bobot kriteria direpresentasikan dalam bentuk matrik bobot kriteria, $\mathrm{W}_{\mathrm{j}}$.

$$
W_{j}=\left[\begin{array}{llll}
w_{1} & w_{2} & \ldots & w_{j}
\end{array}\right]
$$

Normalisasi matriks bobot kriteria dilakukan dengan persamaan : 


$$
W_{j}^{*}=\frac{W_{j}}{\sum_{i=1}^{m} w_{j}} \quad \text { dan } \quad \sum_{j=1}^{m} W_{j}^{*}=1
$$

Dari beberapa field pada dataset, terdapat 5 field yang dijadikan sebagai kriteria pada sistem pendukung keputusan untuk menentukan penerima PKH yaitu :

1) Penghasilan per bulan $\left(\mathrm{C}_{1}\right)$

2) Luas bangunan per orang $\left(\mathrm{C}_{2}\right)$

3) Jenis lantai rumah $\left(\mathrm{C}_{3}\right)$

4) Anak usia 7-15 tahun tidak sekolah $\left(\mathrm{C}_{4}\right)$

5) Pendidikan terakhir kepala keluarga $\left(\mathrm{C}_{5}\right)$

Bobot masing-masing kriteria (Tabel 1) ini ditentukan dengan cara menyebarkan kuisioner kepada 35 orang responden. Setiap responden memberi peringkat pilihan jawaban untuk kelima kriteria, misalkan responden $\mathrm{A}$ mengisi sangat penting untuk $\mathrm{C}_{1}$, sangat penting untuk $\mathrm{C}_{3}$, cukup penting untuk $\mathrm{C}_{2}$, tidak penting untuk $\mathrm{C}_{5}$ dan sangat tidak penting untuk $\mathrm{C}_{4}$. Bobot masing-masing kriteria dihitung berdasarkan penjumlahan keseluruhan jawaban responden untuk setiap kriteria dibagi penjumlahan keseluruhan jawaban responden untuk semua kriteria.

TABEL I

BOBOT KRITERIA YANG DIGUNAKAN

\begin{tabular}{|c|c|c|c|c|c|c|c|}
\hline \multirow[b]{2}{*}{ Kriteria } & \multicolumn{5}{|c|}{ Jawaban Responden } & \multirow[t]{2}{*}{ Bobot } & \multirow{2}{*}{$\begin{array}{c}\text { Normalisasi } \\
\text { Bobot }\end{array}$} \\
\hline & SPS & SP & $\mathbf{C P}$ & $\mathbf{T P}$ & STP & & \\
\hline $\mathrm{C}_{1}$ & 23 & 9 & 3 & 0 & 0 & 161 & 0,310 \\
\hline $\mathrm{C}_{2}$ & 8 & 13 & 13 & 1 & 0 & 134 & 0,258 \\
\hline $\mathrm{C}_{3}$ & 1 & 10 & 13 & 7 & 4 & 103 & 0,199 \\
\hline $\mathrm{C}_{4}$ & 2 & 3 & 4 & 7 & 19 & 68 & 0,131 \\
\hline $\mathrm{C}_{5}$ & 1 & 0 & 2 & 9 & 23 & 53 & 0,102 \\
\hline \multicolumn{6}{|c|}{ Jumlah } & 519 & 1,000 \\
\hline
\end{tabular}

Berdasarkan pada tabel diatas, matrik bobot kriteria ternormalisasi, $W_{j}^{*}$, direpresentasikan,

$$
W_{f}^{*}=\left[\begin{array}{lllll}
0,310 & 0,258 & 0,199 & 0,131 & 0,102
\end{array}\right]
$$

\section{Konversi Nilai Kriteria}

Nilai kriteria yang berbentuk data kualitatif harus diubah ke bentuk data kuantitatif untuk keperluan proses perhitungan pada SPK. Pada Kriteria $C_{1}$ dan $C_{2}$, kita tidak perlu lagi mengkonversi nilai kriteria karena nilainya sudah dalam bentuk data kuantitatif. Namun, pada kriteria $\mathrm{C}_{3}, \mathrm{C}_{4}$ dan $\mathrm{C}_{5}$ masih perlu untuk mengkonversi nilai kriteria karena nilainya belum dalam bentuk data kuantitatif. Kriteria $\mathrm{C}_{3}, \mathrm{C}_{4}$ dan $\mathrm{C}_{5}$ (Tabel 2) termasuk kriteria keuntungan yang artinya semakin besar nilai kriteria yang dimiliki oleh penerima bantuan sosial semakin besar peluangnnya untuk mendapatkan bantuan sosial, artinya nilai besar lebih diinginkan. Untuk kriteria jenis lantai $\left(\mathrm{C}_{3}\right)$, lantai tanah lebih diinginkan dibandingkan lantai semen dan lantai semen lebih diinginkan dibandingkan lantai keramik sehingga lantai tanah dikonversikan ke nilai yang lebih besar dibandingkan nilai lantai semen dan lantai semen dikonversikan ke nilai yang lebih besar dibandingkan nilai lantai keramik. Untuk kriteria anak usia 7-15 tahun tidak sekolah $\left(\mathrm{C}_{4}\right)$, jawaban "ya" lebih diinginkan dibandingkan dengan jawaban tidak karena jawaban "ya" berarti pada keluarga penerima manfaat terdapat anak usia sekolah yang tidak sekolah sehingga nilai jawaban "ya" diberi nilai lebih besar dibandingkan dengan nilai jawaban "tidak". Untuk kriteria pendidikan terakhir kepala keluarga, jawaban tidak sekolah lebih diinginkan daripada jawaban tidak tamat SD, jawaban tidak tamat SD lebih diinginkan daripada tamat SD dan seterusnya sehingga nilai untuk jawaban tidak sekolah lebih besar daripada nilai jawaban tidak tamat SD, nilai untuk jawaban tidak tamat SD lebih besar daripada nilai jawaban tamat SD dan seterusnya.

TABEL II

KONVERSI NILAI KRITERIA C3, C4 DAN C5

\begin{tabular}{|c|c|c|}
\hline \multirow{2}{*}{ Kriteria } & Nilai Kriteria & $\begin{array}{c}\text { Konversi } \\
\text { Nilai }\end{array}$ \\
\hline Lantai Rumah & Keramik & 1 \\
\cline { 2 - 3 }$\left(\mathrm{C}_{3}\right)$ & Semen & 2 \\
\cline { 2 - 3 } & Tanah & 3 \\
\hline $\begin{array}{c}\text { Anak Usia 7-15 Tahun } \\
\text { Tidak Sekolah } \\
\left(\mathrm{C}_{4}\right)\end{array}$ & Tidak & 1 \\
\cline { 2 - 3 } & Ya & 2 \\
\hline $\begin{array}{c}\text { Pendidikan Terakhir } \\
\text { Kepala Keluarga } \\
\left(\mathrm{C}_{5}\right)\end{array}$ & Tamat SMA & 1 \\
\cline { 2 - 3 } & Tamat SMP & 2 \\
\cline { 2 - 3 } & Tamat SD & 3 \\
\cline { 2 - 3 } & Tidak Tamat SD & 4 \\
\cline { 2 - 3 } & Tidak Sekolah & 5 \\
\hline
\end{tabular}

\section{Uji Stabilitas Perangkingan}

Sistem Pendukung Keputusan (SPK) akan menghasilkan perangkingan penerima bantuan sosial dimana penerima manfaat program keluarga harapan yang memiliki skor tertinggi merupakan penerima bantuan sosial yang lebih layak. Misalkan, terdapat 100 data penerima bantuan sosial dan hanya 50 orang saja yang akan diberi bantuan maka dilakukan perangkingan dari nilai skor tertinggi sampai nilai skor terendah dan 50 orang dengan skor tertinggi merupakan penerima bantuan sosial yang layak. Untuk hal ini, sangat penting untuk melihat apakah perubahan bobot kriteria akan mengakibatkan perubahan perangkingan masing-masing altenatif. Uji stabilitas hasil perangkingan dilakukan menggunakan analisis sensitivitas bobot dimensi tunggal. Kisaran bobot kriteria terpenting adalah 0 sampai $\mathrm{w}_{\mathrm{j}}{ }_{\mathrm{j}}$ yang dapat diperoleh dengan persamaan:

$$
\mathbf{w}_{j}^{s}=\left[\left(\mathbf{w}_{\mathrm{jmax}}+(\mathbf{n}-\mathbf{1}) \mathbf{x}\left(\mathbf{w}_{\mathrm{jmin}}\right)\right]\right.
$$

\section{Dimana:}

$\mathrm{W}^{\prime}{ }_{\mathrm{j}}=$ Nilai batas tertinggi bobot kriteria terpenting

$\mathrm{W}_{\text {jmax }}=$ Bobot kriteria tertinggi

$\mathrm{W}_{\text {jmin }}=$ Bobot kriteria terendah

$\mathrm{n} \quad=$ Banyak kriteria

Analisis sensitivitas bobot dimensi tunggal ini didasarkan pada kenyataan bahwa bobot kriteria tidak 
boleh negatif sehingga pada saat melakukan variasi bobot kriteria maka akan ada batasan untuk bobot terpenting. Kestabilan ini diujicoba dengan melakukan variasi nilai bobot kriteria dalam interval kestabilan bobot kriteria. Berdasarkan matrik bobot kriteria ternormalisasi diketahui bahwa kriteria dengan bobot tertinggi, $\mathrm{w}_{\mathrm{jmax}}$, adalah penghasilan $\left(\mathrm{C}_{1}\right)$ sebesar 0,310 dan kriteria dengan bobot terendah, $\mathrm{w}_{\mathrm{jmin}}$, adalah pendidikan terakhir kepala keluarga $\left(C_{5}\right)$ sebesar 0,102 . Kisaran nilai bobot tertinggi ditentukan berdasarkan persamaan 5 ,

$w_{j}^{g}=[(0,310+(5-1) x 0,102]=0,440$

Bobot kriteria tertinggi untuk kriteria penghasilan $\left(\mathrm{C}_{1}\right)$ adalah 0,440. Pada penelitian ini akan dilakukan uji coba dengan 6 variasi bobot kriteria (Tabel 3), dimana kisaran interval bobot untuk kriteria penghasilan $0,115 \leq \mathrm{W}_{\mathrm{C} 1} \leq 0,440$. Setiap perubahan bobot kriteria $\mathrm{C}_{1}$ akan mengakibatkan perubahan bobot kriteria untuk kriteria-kriteria yang lainnya.

TABEL III

VARIASI BOBOT KRITERIA

\begin{tabular}{|c|c|c|c|c|c|}
\hline Variasi Bobot & \multicolumn{5}{|c|}{ Kriteria } \\
\cline { 2 - 6 } Kriteria & $\mathrm{C}_{1}$ & $\mathrm{C}_{2}$ & $\mathrm{C}_{3}$ & $\mathrm{C}_{4}$ & $\mathrm{C}_{5}$ \\
\hline Variasi 1 & 0,115 & 0,307 & 0,248 & 0,180 & 0,151 \\
\hline Variasi 2 & 0,180 & 0,291 & 0,232 & 0,164 & 0,135 \\
\hline Variasi 3 & 0,245 & 0,274 & 0,215 & 0,147 & 0,118 \\
\hline Variasi 4 & 0,310 & 0,258 & 0,199 & 0,131 & 0,102 \\
\hline Variasi 5 & 0,375 & 0,242 & 0,183 & 0,114 & 0,086 \\
\hline Variasi 6 & 0,440 & 0,225 & 0,166 & 0,098 & 0,069 \\
\hline
\end{tabular}

\section{HASIL DAN PEMBAHASAN}

\section{A. Implementasi Perhitungan WPM}

Pada implementasi perhitungan menerapkan WPM pada SPK menentukan penerima bantuan sosial, dilakukan tahap preprosesing data mengubah data penghasilan perbulan dalam satuan juta, memisahkan data field tempat tinggal yang terdiri dari luas tempat tinggal dan jenis lantai menjadi dua field yaitu luas tempat tinggal dan jenis lantai. Selanjutnya melakukan konversi data kualitatif menjadi data kuantitatif menggunakan tabel konversi (Tabel 2). Tahap preprosesing ini dilakukan untuk memastikan semua data untuk field kriteria dalam bentuk data kuantitatif guna mempermudah proses perhitungan WPM. Hasil Preprocessing data untuk 292 PKH dapat dilihat pada Tabel 4.

Selanjutnya adalah menentukan nilai preferensi untuk setiap alternatif penerima $\mathrm{PKH}$, dilakukan dengan cara memangkatkan nilai atribut dengan nilai normalisasi bobot kriteria, $\mathrm{W}_{\mathrm{j}}$. Ketentuan yang berlaku adalah untuk kriteria yang termasuk dalam kriteria biaya (cost) maka nilai pangkat bernilai negatif sedangkan untuk kriteria yang termasuk dalam kriteria keuntungan (benefit) maka nilai pangkat bernilai positif $(+)$. Nilai preferensi ini direpresentasikan pada vektor $S_{i}$, yang diperoleh menggunakan persamaan 1 .
TABEL IV

HASIL PREPROSESING DATA UNTUK 292 PKH

\begin{tabular}{|c|c|c|c|c|c|}
\hline $\begin{array}{c}\text { No } \\
\text { Peserta } \\
\text { PKH }\end{array}$ & $\begin{array}{c}\text { Nilai Kriteria } \\
\text { Juta }\end{array}$ & $\begin{array}{c}\mathbf{C}_{\mathbf{2}}(\mathbf{-} \\
\mathbf{\mathbf { m } ^ { 2 }}\end{array}$ & $\begin{array}{c}\mathbf{C}_{\mathbf{3}} \mathbf{( + )} \\
\text { Konversi }\end{array}$ & $\begin{array}{c}\mathbf{C}_{\mathbf{4}}(+) \\
\text { Konversi }\end{array}$ & $\begin{array}{c}\mathbf{C}_{\mathbf{5}} \mathbf{( + )} \\
\text { Konversi }\end{array}$ \\
\hline 1. & 0,45 & 7 & 2 & 1 & 4 \\
\hline 2. & 0,70 & 10 & 2 & 2 & 3 \\
\hline 3. & 0,40 & 6 & 3 & 2 & 4 \\
\hline 4. & 1,3 & 15 & 1 & 2 & 1 \\
\hline 5. & 0,35 & 6 & 3 & 1 & 4 \\
\hline$\ldots$ & $\ldots$ & $\ldots$ & $\ldots$ & $\ldots$ & $\ldots$ \\
\hline 90 & 0,25 & 5 & 3 & 2 & 5 \\
\hline$\ldots$ & $\ldots$ & $\ldots$ & $\ldots$ & $\ldots$ & $\ldots$ \\
\hline 219 & 1,30 & 14 & 1 & 1 & $\ldots$ \\
\hline$\ldots$ & $\ldots$ & $\ldots$ & $\ldots$ & $\ldots$ & 1 \\
\hline 288 & 0,60 & 8,5 & 3 & 1 & 2 \\
\hline 289 & 0,10 & 10 & 1 & 1 & 3 \\
\hline 290 & 0,75 & 9 & 2 & 1 & 4 \\
\hline 291 & 0,45 & 6,5 & 3 & 1 & 2 \\
\hline 292 & 0,55 & 7 & 3 & 1 & \\
\hline & & & & & $\ldots$ \\
\hline
\end{tabular}

Selanjutnya adalah menentukan nilai preferensi untuk setiap alternatif penerima $\mathrm{PKH}$, dilakukan dengan cara memangkatkan nilai atribut dengan nilai normalisasi bobot kriteria, $\mathrm{W}_{\mathrm{j}}$. Ketentuan yang berlaku adalah untuk kriteria yang termasuk dalam kriteria biaya (cost) maka nilai pangkat bernilai negatif sedangkan untuk kriteria yang termasuk dalam kriteria keuntungan (benefit) maka nilai pangkat bernilai positif $(+)$. Nilai preferensi ini direpresentasikan pada vektor $\mathrm{S}_{\mathrm{i}}$, yang diperoleh menggunakan persamaan 1 .

$$
\begin{aligned}
& S_{1}=0,45^{-0115}+7^{-0,307}+2^{0,248}+1^{0,180}+4^{0,151}=5,06683 \\
& S_{2}=0,70^{-0115}+10^{-0,307}+2^{0,248}+2^{0,180}+3^{0,151}=5,03593 \\
& S_{2}=0,40^{-0115}+6^{-0,307}+3^{0,248}+2^{0,180}+4^{0,151}=5,36696 \\
& S_{4}=1,30^{-0115}+1^{-0,307}+1^{0,248}+2^{0,180}+1^{0,151}=4,53861 \\
& \cdots \\
& S_{5}=0,35^{-0115}+6^{-0,307}+3^{0,248}+1^{0,180}+4^{0,151}=5,25127 \\
& S_{90}=0,25^{-0115}+5^{-0,307}+3^{0,248}+2^{0,180}+5^{0,151}=5,50413 \\
& S_{2,19}=1,30^{-0115}+14^{-0,307}+1^{0,249}+1^{0,180}+1^{0,151}=4,41505 \\
& S_{292}=0,55^{-0115}+7^{-0,307}+3^{0,248}+1^{0,180}+2^{0,151}=5,04449
\end{aligned}
$$

Langkah selanjutnya adalah merangking alternatif $\mathrm{PKH}$ dengan melakukan normalisasi vektor $\mathrm{S}$ menggunakan persamaan 2, hasil perhitungan ini direpresentasikan sebagai vektor $\mathrm{V}_{\mathrm{j}}$.

$$
\begin{aligned}
& V_{1}=\frac{5,06683}{1221,9}=0,00415 \\
& V_{2}=\frac{5,03593}{1221,9}=0,00412 \\
& V_{a}=\frac{5,36696}{1221,9}=0,00439
\end{aligned}
$$




$$
\begin{aligned}
& V_{4}=\frac{4,53861}{1221,9}=0,00371 \\
& V_{5}=\frac{5,25127}{1221,9}=0,00430 \\
& V_{90}=\frac{4,57075}{1221,9}=0,00454 \\
& V_{219}=\frac{3,64288}{1221,9}=0,00364 \\
& V_{292}=\frac{4,19247}{1221,9}=0,00416
\end{aligned}
$$

Nilai vektor ini menunjukkan nilai skor untuk masingmasing penerima bantuan sosial. Semakin tinggi nilai skor vektor $\mathrm{V}_{\mathrm{j}}$ semakin layak alternatif penerima bantuan sosial itu untuk menjadi keluarga penerima manfaat.

\section{TABEL V}

HASIL PERANGKINGAN VARIASI BOBOT 1

\begin{tabular}{|c|c|}
\hline $\begin{array}{c}\text { Variasi } \\
\text { Bobot }\end{array}$ & Hasil Perangkingan PKH \\
\hline 0.115 & $90,168,249,42,197,130,143,234,7,21,3,14,141$, \\
0.307 & $180,265,119,146,39,145,111,51,92,252,224,253$, \\
0.248 & $213,132,149,80,194,136,77,58,193,45,270,175$, \\
0.180 & $158,164,60,237,97,84,183,100,232,50,202,242$, \\
0.151 & $109,276,69,215,91,271,23,36,283,246,257,1172$, \\
& $207,258,5,24,210,217,278,28,68,125,29,154$, \\
& $166,65,291,238,134,138,186,203,281,287,116$, \\
& $118,228,49,284,263,89,56,32,87,155,190,117$, \\
& $273,129,144,223,209,282,81,66,269,182,106,105$, \\
& $163,169,176,248,113,159,272,128,212,244,73$, \\
& $121,240,110,40,196,260,148,192,142,2,221,1,52$, \\
& $156,292,286,107,256,95,12,43,79,27,47,19,233$, \\
& $131,120,61,187,254,167,63,152,136,205,99,171$, \\
& $160,188,10,178247,251,59,93,22,239,57,78,25$, \\
& $112,150,179,222,227,76,83,88,214,101,48,72$, \\
& $53,11,35,290,280,17,206,262,96,165,38,147,30$ \\
& $199,82,104,26,288,6,94,184,259,191,279,123$, \\
& $103,102,174,13,54,275,230,274,189,126,135$, \\
& $201,218,200,243,64,225,9,195,226,264,71,62,55$, \\
& $137,20,161,86,245,115,74,35,211,151,208,31$, \\
& $127,41,33,75,216,44,15,255,268,37,229,34,266$, \\
& $253,177,70,250,170,181,8,289,46,261,16,98,277$, \\
& $198,231,285,157,267,114,235,139,140,67,162,4$, \\
& $18133,241,122,108,204,220,124,173,185,219$ \\
\hline &
\end{tabular}

Hasil perangkingan pada Tabel 5 menunjukkan bahwa penerima bantuan sosial ke 90 berada diposisi pertama, penerima bantuan sosial ke 168 berada diposisi kedua dan seterusnya sampai penerima bantuan sosial 219 berada diposisi 292. Posisi ini menunjukkan tingkat kelayakan penerima bantuan sosial tersebut untuk menjadi keluarga penerima manfaat.

\section{B. Implementasi Sistem Pendukung Keputusan}

Hasil perhitungan SPK untuk menentukan penerima bantuan sosial dengan menerapkan Weighted Product Method (WPM). Perhitungan dengan menerapkan WPM dan hasil perangkingan alternatif penerima bantuan sosial pada 6 variasi bobot kriteria dapat dilihat pada Gambar 1.

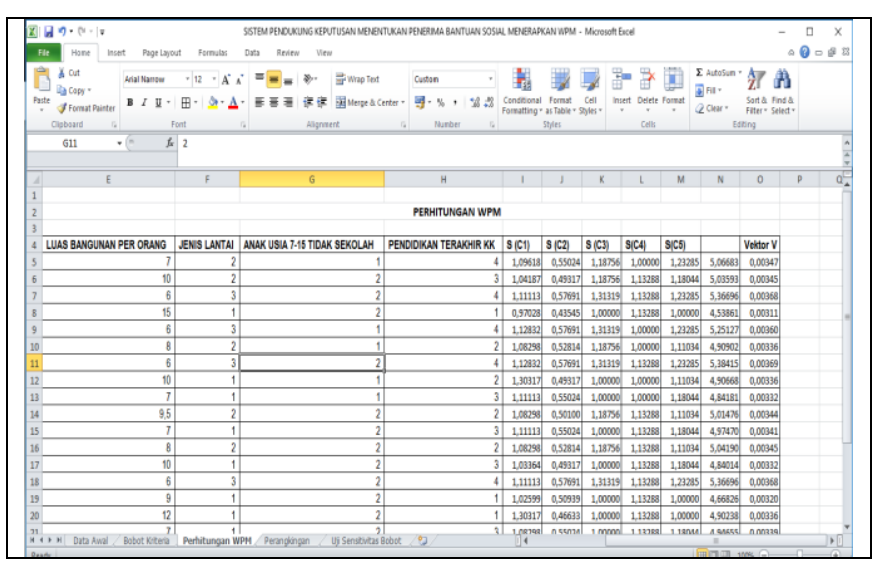

Gambar 1. Implementasi perhitungan WPM untuk kasus variasi bobot 1

Pada sistem pendukung keputusan ini terdapat beberapa sheet yaitu data awal, bobot kriteria, perhitungan WPM, hasil perangkingan dan uji sensitivitas bobot. Hasil perhitungan WPM berupa nilai vektor $\mathrm{V}$ untuk masing-masing penerima bantuan sosial, yang selanjutnya dilakukan perangkingan alternatif (Gambar 2) berdasarkan nilai vektor $\mathrm{V}$.

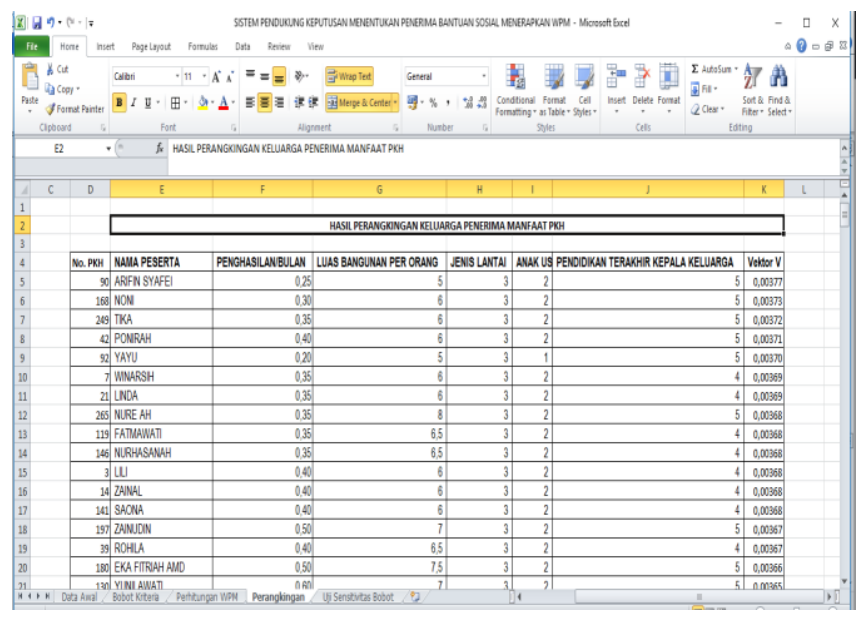

Gambar 2. Implementasi perangkingan PKH untuk kasus variasi bobot 1

\section{Analisis Sensitivitas Bobot}

Analisis sensitivitas bobot dilakukan dengan menggunakan analisis sensivitas bobot dimensi tunggal. Analisis ini menghasilkan grafik (Gambar 3) yang menunjukkan kestabilan hasil perangkingan WPM untuk setiap data penerima bantuan sosial.

Untuk data yang besar, posisi rangking untuk masingmasing data PKH tetap mengalami perubahan posisi, namun perubahan posisi tersebut tidak terlalu signifikan. Klasifikasi kestabilan posisi masing-masing data $\mathrm{PKH}$ dibagi menjadi 3, yaitu KPM yang sangat stabil, KPM yang stabil dan KPM yang tidak stabil. KPM yang sangat stabil adalah penerima bantuan sosial ini tetap berada diperingkat yang sama pada saat 6 kali uji coba variasi bobot kriteria, KPM yang stabil adalah penerima yang 
perubahan posisi rangkingnya hanya berubah paling besar 5 posisi keatas atau 5 posisi ke bawah dan KPM yang tidak stabil adalah penerima yang perubahan posisi rangkingnya minimal 6 posisi keatas atau 6 posisi kebawah. Hasil kestabilan perangkingan dapat dilihat pada Tabel 6.

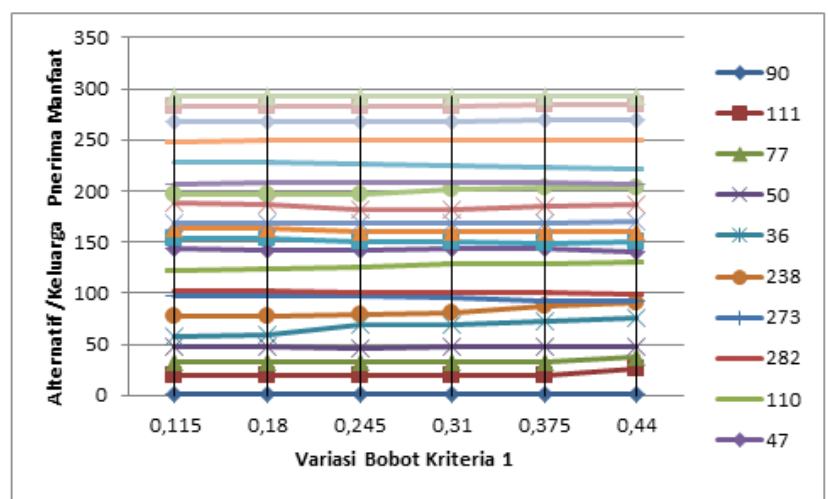

Gambar 3. Hasil uji stabilitas bobot kriteria untuk 6 variasi bobot kriteria

Salah satu peserta PKH yang posisinya sangat stabil adalah peserta ke 90 dan peserta ke 219. Penerima yang paling layak adalah bantuan sosial ke 90 karena secara konsisten penerima bantuan ini selalu berada di peringkat pertama (memiliki nilai vektor $\mathrm{V}$ yang paling besar). Berdasarkan data awal yang ada, penerima bantuan ke 90 ini memiliki data penghasilan sebesar 0.25 juta, luas tempat tinggal per orang sebesar $5 \mathrm{~m}^{2}$, jenis lantai adalah tanah, memiliki anak usia 7-15 tahun yang tidak sekolah dan pendidikan terakhir kepala keluarga adalah tidak sekolah, yang berarti penerima bantuan ini merupakan penerima bantuan yang "paling miskin" diantara penerima bantuan yang ada. Sebaliknya penerima bantuan yang ke 219 juga selalu konsisten berada di peringkat yang terakhir (memiliki nilai vektor $\mathrm{V}$ yang paling kecil). Berdasarkan data awal yang ada, penerima bantuan ke 219 ini memliki data penghasilan sebesar 1.3 juta, luas tempat tinggal per orang sebesar $14 \mathrm{~m}^{2}$, jenis lantai adalah keramik, tidak memiliki anak usia 7-15 tahun yang tidak sekolah dan pendidikan terakhir kepala keluarga adalah tamat SMA, yang berarti penerima bantuan ini merupakan penerima bantuan yang "paling kaya" diantara penerima bantuan yang ada. Alternatif PKH 90, 168, 249 dan 42 selalu konsisten di peringkat atas karena alternatif ini memiliki nilai kriteria $C_{1}$ dan $C_{2}$ yang rendah dan memiliki nilai kriteria $\mathrm{C}_{3}, \mathrm{C}_{4}$ dan $\mathrm{C}_{5}$ yang tinggi. Data alternatif PKH 178, 239, 254, 204, 124, 173, 185 dan 219 selalu konsisten berada di peringkat bawah karena memiliki nilai kriteria $C_{1}$ dan $C_{2}$ yang tinggi dan memiliki nilai kriteria $\mathrm{C}_{3}, \mathrm{C}_{4}$ dan $\mathrm{C}_{5}$ yang rendah.
TABEL VI

HASIL KESTABILAN PERANGKINGAN

\begin{tabular}{|c|c|c|c|}
\hline $\begin{array}{l}\text { Klasifikasi } \\
\text { Kestabilan }\end{array}$ & Nomor Peserta PKH & $\begin{array}{c}\text { Jumlah } \\
\text { Data }\end{array}$ & $\%$ \\
\hline $\begin{array}{l}\text { KPM yang } \\
\text { sangat } \\
\text { stabil }\end{array}$ & $\begin{array}{l}90,168,249,42,7,21,3,14, \\
141,197,130,143,234,119, \\
146,39,180,265,145,111, \\
51,224,253,132,92,136, \\
194,58,252,213,45,80,77, \\
270,60,149,84,237,158, \\
164,175,193,242,183,271, \\
283,100,50,202,69,232, \\
56,138,73,240,178,239, \\
254,204,124,173,185,219\end{array}$ & 63 & 21,6 \\
\hline $\begin{array}{l}\text { KPM yang } \\
\text { stabil }\end{array}$ & $\begin{array}{l}215,110,28,97,68,257, \\
246,5,24,210,217,278,23, \\
172,207,258,91,118,291, \\
36,125,154,166,65,134, \\
32,87,155,190,263,29, \\
281,89,284,116,238,228, \\
209,273,186,203,144,287, \\
49,117,282,81,129,223, \\
66,269,105,244,248,113, \\
159,272,128,212,221,40, \\
120,192,2,63,1,52,156, \\
286,256,12,43,131,152, \\
251,59,76,93,10,27,22, \\
78,188,112,25,83,88,150, \\
179,57,222,227,214,38, \\
147,53,82,290,280,206, \\
165,11,35,17,191,26,6, \\
94,184,279,101,48,72, \\
102,199,54,230,274,96, \\
126,201,135,218,200,243, \\
275,226,13,264,104, \\
137,86,225,115,64,9,195, \\
245,74,85,55,208,31,62, \\
20,161,33,75,211,127,41, \\
44,15,216,268,255,37, \\
229,34,266,153,177,70, \\
250,67,8,289,170,181,46, \\
261,16,98,277,198,231, \\
285,157,267,235,140,139, \\
162,4,114,133,241,18, \\
122,220,108,61,187,259, \\
103\end{array}$ & 197 & 67,5 \\
\hline $\begin{array}{l}\text { KPM yang } \\
\text { tidak stabil }\end{array}$ & $\begin{array}{l}182,106,163,169,176,167, \\
19,30,189,123,71,151, \\
205,160,292,148,196,260, \\
288,262,121,142,110,95, \\
107,236,99,171,247,79, \\
47,233,174\end{array}$ & 32 & 10,9 \\
\hline \multicolumn{2}{|r|}{ Jumlah Keseluruhan } & 292 & 100 \\
\hline
\end{tabular}

\section{KESIMPULAN}

Berdasarkan pembahasan diatas dapat diambil kesimpulan sebagai berikut :

1) Sistem pendukung keputusan yang dibangun dapat mendukung Dinas Sosial untuk memberikan keputusan yang lebih objektif sehingga Keluarga Penerima Manfaat yang lebih berhak mendapatkan prioritas atau posisi rangking di posisi atas. 
2) Pada Weighted Product Method (WPM) akan dihasilkan solusi ideal yang meminimalkan nilai kriteria biaya (-) dimana semakin kecil nilai pada kriteria biaya akan semakin besar peluang alternatif PKH untuk berada di posisi peringkat atas dan memaksimalkan nilai kriteria keuntungan $(+)$ dimana semakin besar nilai kriteria keuntungan akan semakin besar pula peluang alternatif PKH untuk berada di posisi peringkat atas.

3) Pada uji coba 6 variasi bobot kriteria, kestabilan posisi rangking peserta KPM, metode Weighted Product Method (WPM dapat dikatakan cukup stabil karena menghasilkan 21,6\% KPM yang posisinya sangat stabil dan $67,5 \%$ KPM yang posisinya stabil sehingga $89,1 \%$ posisi rangking KPM dikatakan stabil.

\section{REFERENSI}

[1] P. Putra and Sahara, "DAMPAK PROGRAM BANTUAN SOSIAL The effect Of Social Aid To Economic Growth And Poverty," J. Ekon. Pembang., vol. 17, no. 3, pp. 161-171, 2015.

[2] H. L. Nurul Najidah, "EFEKTIVITAS PROGRAM KELUARGA HARAPAN (PKH) DI KELURAHAN ROWOSARI KECAMATAN TEMBALANG KOTA SEMARANG," J. Public Policy Manag. Rev., vol. 8, no. 2, pp. 69-87, 2019.

[3] C. Usman, "Efektivitas Program Keluarga Harapan (PKH) dalam Rangka Penanggulangan Kemiskinan (Suatu Studi di Kecamatan Kota Utara Kota Gorontalo)," J. Adm. Publik Unsrat, vol. 2, no. 1, pp. 1-13, 2014

[4] I. Muzakkir, "Penerapan metode topsis untuk sistem pendukung keputusan penentuan keluarga miskin pada desa panca karsa ii," Ilk. J. Ilm. Vol. 9 Nomor 3 Desember 2017, vol. 9, pp. 274-281, 2017.

[5] V. G. S and M. C. S, "Comparative Study of Different Multicriteria Decision-making Methods," Int. J. Adv. Comput. Theory Eng., vol. 2, no. 4, pp. 9-12, 2013.

[6] A. Setyawan, F. Y. Arini, and I. Akhlis, "Comparative Analysis of Simple Additive Weighting Method and Weighted Product Method to New Employee Recruitment Decision Support System (DSS) at PT. Warta Media Nusantara," Sci. J. Informatics, vol. 4, no. 1, pp. 34-42, 2017.

[7] Andriyendi, "Multi-Attribute Decision Making Using Simple Additive Weighting and Weighted Product in Food Choice," I.J. Inf. Eng. Electron. Bus., vol. 6, no. November, pp. 8-14, 2015.

[8] R. Rekik, Ilhem Kallel, J. Casillas, and A. M. Alimi, "Using multiple criteria decision making approaches to assess the quality of web sites," Int. J. Comput. Sci. Inf. Secur., vol. 14, no. 7, pp. 747-761, 2016.

[9] R. Ghasempour, M. Alhuyi, and M. Ebrahimi, "Multi-Criteria Decision Making ( MCDM ) Approach for Selecting Solar Plants Site and Technology : A Review," Int. J. Renew. Energy Dev., vol. 8 , no. 1 , pp. 15-25, 2019.

[10] N. Rohmah, D. Remawati, and A. KKW, "Penerapan Metode Weighted Product (Wp) Untuk Penerimaan Pegawai Baru Di Pt. Tiga Serangkai Pustaka Mandiri Surakarta,” J. Ilm. SINUS, pp. 41-58, 2013.

[11] Diana, Metode dan aplikasi sistem pendukung keputusan, 1st ed. Yogyakarta: Penerbit Deepublish, 2018.

[12] C. Handayani, S. Tinggi, I. Komputer, P. Cirebon, and J. Barat, "Sistem Pendukung Keputusan Penerimaan Dana Bantuan Jaminan Kesehatan Masyarakat Untuk Keluarga Miskin Menggunakan Metode Fuzzy Topsis,” J. ICT Inf. Commun. Technol., vol. 18, no. July, pp. 34-40, 2019.

[13] N. G. Khodashahri, M. Mir, and H. Sarabi, "DECISION SUPPORT SYSTEM ( DSS ) Abstract : 1- Introduction : 2Decision support systems concept and some theorist view :," Singaporean J. Bus. Econ. Manag. Stud., vol. 1, no. 6, pp. 95-102, 2013.
[14] R. Rahardian, N. Hidayat, and R. K. Dewi, "Sistem Pendukung Keputusan Penentuan Penerima Bantuan Keluarga Miskin Menggunakan Metode Analytical Hierarchy Process - Preference Ranking Organization for Enrichment Evaluation II ( AHPPROMETHEE II )," J. Pengemb. Teknol. Inf. dan Ilmu Komput., vol. 2, no. 5, pp. 1980-1985, 2017.

[15] A. O. Riyandi, N. Dengen, and Islamiyah, "Sistem Pendukung Keputusan Kelayakan Pemberian Bantuan Dana atau Kredit Untuk Usaha Kecil Menengah (UKM) pada Bank Negara Indonesia (BNI)," Pros. SAKTI (Seminar Ilmu Komput. dan Teknol. Informasi), vol. 2, no. 1, pp. 8-13, 2017.

[16] N. M. Sidiq and A. Wardhana, "Analysis and Design of Decision Support System for Improving School Education Quality Case Study : SMK Aero Dirgantara Islamic Village," IJCSMC, vol. 7, no. 4, pp. 97-108, 2018.

[17] Akmaludin, "Weight Product Model ( Wpm ) for Notebook Selections Dengan Multi Kriteria Berbasis Teknologi," Pilar Nusa Mandiri, vol. XII, no. 2, pp. 111-120, 2016.

[18] R. N. P. Atmojo, A. D. Cahyani, and Y. Lie, "Simulation modeling of tablet PCs selection using weighted-product algorithm," Appl. Math. Sci., vol. 8, no. 115, pp. 5705-5719, 2014. 